Bull. Fac.Agric.,Cairo Univ., 63: 162-173 (2012)

\title{
EFFECT OF PLANT SPECIES, STEM CUTTING TYPE AND PLANTING DATE ON PROPAGATION OF Eranthemum PLANT
}

(Received: 12.2.2012)

\author{
By \\ Sh. M. Mahmood \\ Horticulture Department, Nasser Faculty of Agriculture Sciences, University of Aden-Yemen
}

\begin{abstract}
An experiment was conducted to find out suitable cutting types and planting dates on the success of vegetative propagation of some Eranthemum species. The treatments were four species namely Eranthemum reticulatum , E. nigrum, E.albo-marginatum and E. tricolor, three different types of stem cuttings viz. soft wood, semi- hard wood and hard wood, two planting dates viz. the second week of February and May at the Nasser's Faculty of Agriculture Sciences under shelter house during the two seasons of 2008 and 2009 . The interaction effect between species, cutting types and planting dates showed a decisive result of $100 \%$ rooting percentage in soft wood cuttings of E. reticulatum , E. nigrum, E.albo-marginatum planted in February, while the highest rooting percentages (95.0 and 97.5 ) were achieved in the semi- hard wood cuttings of E. tricolor in February plantation. It was observed that February plantation was favorable for root formation, the maximum numbers of roots (15.33 and 14.60$)$ were produced with soft wood cuttings of $E$. reticulatum, while, the longest roots $(44.80$ and $44.98 \mathrm{~cm})$,the highest fresh weights (10.98 and $7.93 \mathrm{gm})$ and the highest dry weights $(2.38$ and $2.32 \mathrm{gm})$ were recorded in hard wood and semihard wood cuttings of E. reticulatum; E.albo-marginatum and E. reticulatum, respectively. The highest number of shoots (5.32 and 4.97 ) were observed in semi- hard wood and hard wood cuttings of E.albo-marginatum planted in May, while, the lowest numbers of shoot were $(1.25$ and 0.0$)$ in the soft wood cuttings of E. reticulatum planted in February, the longest shoots (25.37 and $21.49 \mathrm{~cm}$ ) were recorded in hard wood cuttings of E. tricolor and E. nigrum in February plantation, whereas ,the maximum number of leaves (39.20 in the first season and 36.83 in the second season ) were found in hard wood cuttings of E. tricolor and E.albo-marginatum planted in February and May, respectively.
\end{abstract}

Key word : eranthemum species, planting dates, rooting, type of stem cuttings, vegetative propagation.

\section{INTRODUCTION}

Eranthemum, Fam. Acanthaceae is a genus including 15 species of erect semi-woody shrubs, natives of south -eastern Africa .A popular foliage shrubs in Yemen, small to medium 1 to $2 \mathrm{~m}$ best suited for hot and humid tropical plains, grown in shade or semi- shade. In our conditions, Eranthemum sp. does not produce seed so it is usually propagated through soft wood stem cuttings. Information on the propagation and production of Eranthemum species in Yemen is not available. Our objective was to determine the use of different types of stem cuttings and standardize the planting date to propagate Eranthemum species with emphasis on how species, cutting type and planting date affect cutting rooting and success of growth in order to provide a theoretical and technical basis for nursery stock production. Previous studies on the effect of species have been reported by various scientists (Paul et al.,1992 and Kibblen et al.,2004 ) who found strong influence on rooting percentage, but (Tetsumura et al.,2001) reported that there were no significant differences on rooting percentage, while, (Aminul et al., 2010) reported that there were no significant differences on longest shoot, leaves number, number and length of root among species. However, broad variation among species for root number, root length, root dry weight were noticed by (Zalesny and Wiese, 2006) . Using different types of cutting are other factors known to increase rooting and success. However, according to Christopher et al.,(2006) 
type of cutting is not an important factor. According to Yeboah et al., (2009) the number of roots was not effected by the type of cutting . Various scientists (Palanisany 1997, Kamal and Hamad, 2006 and Aini Nor et al.,(2010) found the highest rooting for soft wood cuttings , whereas, Aminul et al.,(2010) found the minimum rooting percentage in soft wood cuttings . Regardless to root growth (Christopher et al., (2004 , Koyuncu and Senel (2003) recorded that the number of roots and length of root were significantly influenced by the type of cutting, whereas, Yeboah et al., (2009) recorded that there were no significant influences on the number of roots . However, Laura et al., (1994) showed that hard wood cuttings had the highest root count, total root length and root dry weight. While , Araya et al.,(2007) found that better root length, root number from apical than from basal cuttings. Type of cutting can influence shoot and root growth. Agbo and Obi (2007) found that hard wood cuttings had longer vine as well as higher number of shoots and leaves per cutting Aminul et al.,(2010) recorded similar results , whereas Bannister and Watt,(1995) observed that shoot length was unaffected by the type of cutting. Several researchers investigated the influence of planting date on the rooting percentage,total shoot length,root number and length of root stem cuttings e.g.,Urszula et al .(2003),Bannister and Watt,(1995), Bhardwaj (2005), Yoo et al., (1996) and Araya et al. ( 2007). They showed that cuttings gave the best results when planted in February. The results of two factors interaction recorded by Francois et al., (2010) indicate that the number of roots was significantly affected by the interaction between species and cutting type. Stankova and Panetosos,(1997)found significant effect between species and planting date on rooting percentage and root length . Rooting percentage was greatest with hard wood cutting planted in mid- May according to Paula et al.,(2002) ).While, Kraiem et al. (2010) recorded that the weight of the root depended on the cutting type and planting date, whereas, Zalesny and Wiese, 2006) found that root numbers were achieved when soft wood cuttings were collected in February, and the interaction between species, cutting type and planting date were also significant in terms of root number and dry weight.

\section{MATERIALS AND METHODS}

The experiment of the present study was carried out under shelter house of Nasser's Faculty of Agriculture Sciences during 2008 and 2009 . Stem cuttings were collected from four species Eranthemum reticulatum , E. nigrum, E.albo-marginatum and E. tricolor growing in the faculty campus. It was decided to check rooting percentage and growth of soft wood, semi- hard wood and hard wood cuttings. They are classified into three groups according to maturity or age of wood. Cuttings were prepared from vigorous one- year - old shoots , stems were recut between $15-20 \mathrm{~cm}$ in length for soft wood and semi-hard wood and hard wood cuttings, respectively and planted in polythene bags of $10 \mathrm{~cm}$ size filled with soil during February and May. The experiment consisted of four species, three stem cutting types and two planting dates which gave twenty- four treatment combinations, in a split - split plot design with four replicates ,40 cuttings for each treatment were used and ten cuttings for each replicate. After 90 days, all cuttings were lifted from the polythene bags and evaluated for rooting percentage. The obtained data on shoot and root parameters were recorded as following:

1-Rooting \%

2- Number of roots/cutting

3- Root length

4- Fresh and dry weight of roots/cutting

5- Number of shoots/cutting

6- Length of the longest shoot/cutting

7- Number of leaves/cutting

The data were subjected to an analysis of variance, comparison of mean was performed using ( least significant difference LSD) at $\mathrm{p}=$ 0.05

The rooting percentage was obtained by the following formula:

Cuttings rooted percentage

$$
=\quad \frac{\text { Number of cuttings rooted }}{\text { Total No. of cuttings planted }} \times 100
$$

Monthly temperature during the rooting and growth are presented in Table ( 1 ) as recorded by Civil Aviation \& Meteorology Authority Aden

\section{RESULTS AND DISCUSSION 3.1.Rooting percentage}

It was evident from Table (2) that species were not significantly different from each other. Such results have also been observed by Tetsumura et al.,(2001) on Japanese persimmon. Whereas, Paul et al .(1992) on eastern red cedar 
Table(1): Monthly meteorological parameters during rooting and growth.

\begin{tabular}{|c|c|c|c|c|c|c|}
\hline \multirow{3}{*}{ Month } & \multicolumn{6}{|c|}{$\begin{array}{l}\text { Temperature } \\
\left({ }^{\circ} \mathrm{C}\right)\end{array}$} \\
\hline & \multicolumn{3}{|c|}{$\begin{array}{l}\text { First season } \\
\quad(2008)\end{array}$} & \multicolumn{3}{|c|}{$\begin{array}{c}\text { Second season } \\
(2009)\end{array}$} \\
\hline & Max. & Min. & Mean & Max. & Min. & Mean \\
\hline Feb. & 29.8 & 20.5 & 25.9 & 29.2 & 23.6 & 25.9 \\
\hline March & 32.0 & 20.5 & 26.7 & 29.9 & 23.9 & 26.5 \\
\hline April & 33.7 & 21.5 & 28.4 & 31.7 & 25.4 & 28.1 \\
\hline May & 39.0 & 24.5 & 31.7 & 35.4 & 28.0 & 31.4 \\
\hline June & 39.0 & 28.2 & 31.7 & 37.5 & 29.5 & 32.7 \\
\hline July & 38.0 & 28.0 & 32.6 & 36.8 & 29.2 & 32.2 \\
\hline Aug. & 38.2 & 27.2 & 32.3 & 35.8 & 28.5 & 31.7 \\
\hline Sept. & 38.2 & 26.2 & 31.6 & 36.4 & 28.5 & 31.9 \\
\hline
\end{tabular}

and Kibblen et al.(2004) on Backhousia cibriodora found a strong influence of species on rooting percentage. The significant variation in rooting percentage was noticed between the cuttings with different type Table(2) such as the highest ( 92.8 and $85.6 \%$ ) were found with S.W. cutting in the first and second years, respectively, probably due to higher endogenous auxin which stimulates root initiation from stem cuttings. These results are in agreement with those obtaind by Palanisany (1997) on neem, Kamal and Hamad (2006 ) on Cordia mixa and Aini Nor et al. (2010) on Gonystylus bancanus, but contrary to the finding of Christopher et al. (2006) on Murraya paniculata and Tecoma stans who reported that there was no significant influence in rooting percentage and with Aminul et al.( 2010) on Jatropha curcas who found a lowest rooting percentage for soft wood cuttings, when only the planting date was considered. The rooting percentage was the highest (87.1 and 83.7\%) in February plantation in the first and second years, respectively Table(2), which is in a close conformity to the finding of Urszula et al.(2003) on Azalea. The differences in rooting percentage in different planting dates might be due to different production of endogenous auxin in different seasons and in different environmental conditions under which the stock plants are grown .

Interaction between species and cutting type had significant effect. Rooting percentage was the highest $(96.2 \%)$ in E. nigrum with S.W. cuttings in the first year while, the highest $(92.5 \%)$ was recorded in E. reticulatum with S.W .cutting followed by E. nigrum with S.W.cutting $(91.2 \%)$ in the second year Table (3). The interaction between species and planting date had a significant effect Table (3) .This result corroborated the earlier report of
Table(2): Single effect of species, stem cutting type and planting date on rooting percentage.

\begin{tabular}{|c|c|c|}
\hline \multirow[b]{2}{*}{ Treatment } & \multicolumn{2}{|c|}{ Rooting percentage } \\
\hline & $\begin{array}{c}\text { First } \\
\text { year } \\
2008\end{array}$ & $\begin{array}{c}\text { Second } \\
\text { year } \\
2009\end{array}$ \\
\hline \multicolumn{3}{|l|}{ Species } \\
\hline E. reticulatum & 76.7 & 78.7 \\
\hline E. nigrum & 83.3 & 75.0 \\
\hline E. albo marginatum & 80.4 & 72.9 \\
\hline E. tricolour & 82.9 & 74.2 \\
\hline $\operatorname{LSD}(\mathbf{P}>0.05)$ & n.s. & n.s. \\
\hline \multicolumn{3}{|l|}{ Cutting type } \\
\hline Soft Wood S. W & 92.8 & 85.6 \\
\hline Semi hard Wood S.HW & 85.3 & 78.1 \\
\hline Hard wood H W & 64.4 & 61.9 \\
\hline LSD $(P>0.05)$ & 6.50 & 6.06 \\
\hline \multicolumn{3}{|l|}{ Planting date } \\
\hline February & 87.1 & 83.7 \\
\hline May & 74.6 & 66.7 \\
\hline $\operatorname{LSD}(\mathbf{P}>0.05)$ & 5.31 & 4.95 \\
\hline
\end{tabular}

Stankova and Panetosos (1997) on Cupressus sempervirens.Table (3) shows that species have different rooting percentage at different planting date ,the highest rooting percentages ( 97.5 and $92.5 \%$ ) were recorded in cuttings of E. nigrum and E. reticulatum in February plantation in the first and second years, respectively .There were significant effects of the interaction between cutting type and planting date. Table (3) shows a lower percentage of rooting (57.5 and 53.1\%) with H.W. cuttings planted in May compared to the highest ( 96.9 and $93.1 \%$ ) with S.W. cuttings planted in February in the first and second seasons, respectively. This result is in contrary to the finding of Paula et al. (2002)on Juglans cinerea.

The interaction between species, cutting type and planting date Table (4) showed that $(100 \%$ rooting) was obtained with S.W. cuttings of $E$. nigrum, E.albo-marginatum and E. reticulatum planted in February. However, the highest rooting percentages (97.5) 97.5 and $97.5 \%$ were achieved in S.H.W cuttings of E. tricolor planted in February in the second year, in S.H.W. cutting of E. nigrum planted in Feb. in the first year with $E$. reticulatum in Febrauary in the second year, respectively.

\subsection{Root growth}

\subsubsection{Number of roots per cutting}

Table(5) revealed that there was a significant difference between species in the number of roots, which is in a close conformity to the finding of Zalesny and Wiese (2006). The highest number of roots ( 11.16 and 10.37 ) were observed in cuttings of E. albo-marginatum in 
Table (3): Interaction effect between species , stem cutting type and planting date on rooting percentage (Ineraction between two factors).

\begin{tabular}{|c|c|c|}
\hline \multirow[t]{2}{*}{ Treatments } & \multicolumn{2}{|c|}{$\begin{array}{c}\text { Rooting } \\
\text { percentage }\end{array}$} \\
\hline & $\begin{array}{l}\text { First } \\
\text { year }\end{array}$ & $\begin{array}{l}\text { Second } \\
\text { year }\end{array}$ \\
\hline \multicolumn{3}{|l|}{ Species x Cutting type } \\
\hline E.reticulatum X S. W & 87.5 & 92.5 \\
\hline E. reticulatum $\mathbf{X}$ S.HW & 81.2 & 82.5 \\
\hline E. reticulatum $\mathbf{X} \mathbf{H W}$ & 61.2 & 61.2 \\
\hline E.nigrum X S. W & 96.2 & 91.2 \\
\hline E. nigrum X S.HW & 85.0 & 76.2 \\
\hline E. nigrum X HW & 68.7 & 57.5 \\
\hline E.albo marginatum $\mathbf{X} \mathbf{S} . \mathbf{W}$ & 95.0 & 85.0 \\
\hline E.albo marginatum $\mathbf{X}$ S.HW & 81.2 & 67.5 \\
\hline E. albo marginatum $\mathbf{X} \mathbf{H W}$ & 65.0 & 66.2 \\
\hline E.tricolour X S. W & 92.5 & 73.8 \\
\hline E. tricolour X S.HW & 93.7 & 86.2 \\
\hline E. tricolour $\mathbf{X} \mathbf{H W}$ & 62.5 & 62.5 \\
\hline $\mathrm{LSD}(\mathrm{P}>0.05)$ & $\mathbf{1 3 . 0}$ & 12.12 \\
\hline \multicolumn{3}{|l|}{ Species x Planting date } \\
\hline E. reticulatum $\mathbf{X}$ Feb. & 85.8 & 92.5 \\
\hline E. reticulatum X. May & 67.5 & 65.0 \\
\hline E. nigrum X Feb. & 97.5 & 78.3. \\
\hline E. nigrum X May & 69.2 & 71.7 \\
\hline E. albo marginatum $\mathbf{X}$ Feb. & 81.7 & 78.3 \\
\hline E. albo marginatum $\mathbf{X}$ May & 79.2 & 67.5 \\
\hline E. tricolour X Feb. & 83.3 & 85.8 \\
\hline E. tricolour X May & 82.5 & 62.0 \\
\hline $\mathbf{L S D}(\mathbf{P}>\mathbf{0 . 0 5})$ & 10.62 & 9.90 \\
\hline \multicolumn{3}{|l|}{ Cutting type $x$ Planting date } \\
\hline S. W X Feb. & 96.9 & 93.1 \\
\hline S. W X May & 88.7 & 78.1 \\
\hline S.HW X Feb & 93.1 & 87.5 \\
\hline S.HWX May & 77.5 & 68.8 \\
\hline HW X Feb & 71.2 & 70.6 \\
\hline HW X May & 57.5 & 53.1 \\
\hline $\mathrm{LSD}(\mathrm{P}>0.05)$ & 9.19 & 8.57 \\
\hline
\end{tabular}

the first and second years, respectively whereas , the minimum ( 9.35 and 8.04 ) in cuttings of $E$. tricolor in the first and second years, respectively. Significant effect of cutting type was observed Table (5). This result is in accordance with those of Koyuncu and Senel (2003) and in contrary to the finding of Yeboah et al. (2009). The highest numbers of roots ( 11.46 and 9.77) were obtained with S.W. cuttings whereas, the minimum ( 9.45 and 8.84 ) in H.W. cuttings in the first and second years, respectively, Araya et al. (2007) also obtained similar result. The increase in the number of roots with S.W. cuttings may be due to indol actic acid ( IAA) which is synthesized in the shoot tip and translocated to the basal portion and is active in inducing root formation. The results in Table (5) showed that the number of
Table(4):Interaction effect between species, stem cutting type and planting date on rooting percentage. (Interaction between three factors together).

\begin{tabular}{|l|c|c|}
\hline \multirow{2}{*}{ Treatments } & \multicolumn{2}{c|}{$\begin{array}{c}\text { Rooting } \\
\text { percentage }\end{array}$} \\
\cline { 2 - 3 } & $\begin{array}{c}\text { First } \\
\text { year }\end{array}$ & $\begin{array}{c}\text { Second } \\
\text { year }\end{array}$ \\
\hline E. reticulatum X S. WX Feb. & $\mathbf{9 2 . 5}$ & $\mathbf{1 0 0}$ \\
\hline E. reticulatum X S. WX May & $\mathbf{8 2 . 5}$ & $\mathbf{8 5 . 0}$ \\
\hline E. reticulatum X S.HWX Feb & $\mathbf{9 0 . 0}$ & $\mathbf{9 7 . 5}$ \\
\hline E. reticulatum X S.HWX May & $\mathbf{7 2 . 5}$ & $\mathbf{6 7 . 5}$ \\
\hline E. reticulatum X HW X Feb. & $\mathbf{7 5 . 0}$ & $\mathbf{8 0 . 0}$ \\
\hline E. reticulatum X HWX May & $\mathbf{4 7 . 5}$ & $\mathbf{4 2 . 5}$ \\
\hline E. nigrum X S. WX Feb. & $\mathbf{1 0 0}$ & $\mathbf{9 5 . 0}$ \\
\hline E. nigrum X S. WX May & $\mathbf{9 2 . 5}$ & $\mathbf{8 7 . 5}$ \\
\hline E. nigrum X S.HWX Feb & $\mathbf{9 7 . 5}$ & $\mathbf{8 0 . 0}$ \\
\hline E. nigrum X S.HWX May & $\mathbf{7 2 . 5}$ & $\mathbf{7 2 . 5}$ \\
\hline E. nigrum X HW X Feb. & $\mathbf{9 5 . 0}$ & $\mathbf{6 0 . 0}$ \\
\hline E. nigrum X HWX May & $\mathbf{4 2 . 5}$ & $\mathbf{5 5 . 0}$ \\
\hline E. albo marginatum X S. WX Feb. & $\mathbf{1 0 0}$ & $\mathbf{9 5 . 0}$ \\
\hline E. albo marginatum X S. WX May & $\mathbf{9 0 . 0}$ & $\mathbf{7 5 . 0}$ \\
\hline E. albo marginatum X S.HWX Feb & $\mathbf{9 0 . 0}$ & $\mathbf{7 5 . 0}$ \\
\hline E. albo marginatum X S.HWX May & $\mathbf{7 2 . 5}$ & $\mathbf{6 0 . 0}$ \\
\hline E. albo marginatum X HW X Feb. & $\mathbf{5 5 . 0}$ & $\mathbf{6 5 . 0}$ \\
\hline E. albo marginatum X HWX May & $\mathbf{7 5 . 0}$ & $\mathbf{6 7 . 5}$ \\
\hline E. tricolour X SWX Feb & $\mathbf{9 5 . 0}$ & $\mathbf{8 2 . 5}$ \\
\hline E. tricolour X S. WX May & $\mathbf{9 0 . 0}$ & $\mathbf{6 5 . 0}$ \\
\hline E. tricolour X S.HWX Feb & $\mathbf{9 5 . 0}$ & $\mathbf{9 7 . 5}$ \\
\hline E. tricolour X S.HWX May & $\mathbf{9 2 . 5}$ & $\mathbf{7 5 . 0}$ \\
\hline E. tricolour XHWX Feb & $\mathbf{6 0 . 0}$ & $\mathbf{7 7 . 5}$ \\
\hline E. tricolour X HWX May & $\mathbf{6 5 . 0}$ & $\mathbf{4 7 . 5}$ \\
\hline LSD(P>0.05) & $\mathbf{1 8 . 3 9}$ & $\mathbf{1 7 . 1 4}$ \\
\hline & & \\
\hline
\end{tabular}

roots was significantly influenced by planting date in both years, and the highest numbers of roots (10.87 and 10.46 cutting) were recorded in February plantation in the first and second years, respectively. Similar effect of planting date was also reported by Bhardwaj (2005).The interaction effect of species and type of cutting having significant influence (Table 6). Such result has also been observed by Francois et al.(2010) , S.W. cuttings of E. reticulatum produced the highest number of roots (13.0 and 11.84 ) in the first and second years, respectively. The interaction between species and planting date had significant effect on the number of roots Table (6), cuttings of E. albo-marginatum planted in February produced the highest number of roots ( 12.50 and 11.48 ) in the first and second years respectively while, cuttings of E. tricolor planted in May recorded the least number of roots ( 8.28 and 6.11) in the first and the second seasons, respectively.The interaction effect of cutting type and planting date significantly affected the number of roots Table (6).S.W.cuttings planted in February had the highest values 12.56 and 11.02 in the first and second years, respectively. This result corroborated the earlier report of Zalesny and 
Table (5): Single effect of species ,stem cutting type and planting date on root parameters per cutting.

\begin{tabular}{|c|c|c|c|c|c|c|c|c|}
\hline \multirow{3}{*}{ Treatments } & \multicolumn{8}{|c|}{ Root parameters } \\
\hline & \multicolumn{2}{|c|}{ Number of roots } & \multicolumn{2}{|c|}{$\begin{array}{c}\text { Length of roots } \\
(\mathrm{cm})\end{array}$} & \multicolumn{2}{|c|}{$\begin{array}{c}\text { Fresh weight of } \\
\text { roots }(\mathrm{gm})\end{array}$} & \multicolumn{2}{|c|}{$\begin{array}{l}\text { Dry weight of } \\
\text { roots (gm) }\end{array}$} \\
\hline & $\begin{array}{l}\text { First } \\
\text { year }\end{array}$ & $\begin{array}{c}\text { Second } \\
\text { year }\end{array}$ & $\begin{array}{l}\text { First } \\
\text { year }\end{array}$ & $\begin{array}{c}\text { Second } \\
\text { year }\end{array}$ & $\begin{array}{l}\text { First } \\
\text { year }\end{array}$ & $\begin{array}{c}\text { Second } \\
\text { year }\end{array}$ & $\begin{array}{l}\text { First } \\
\text { year }\end{array}$ & $\begin{array}{c}\text { Second } \\
\text { year }\end{array}$ \\
\hline \multicolumn{9}{|l|}{ Species } \\
\hline E. reticulatum & 10.26 & 9.63 & 35.65 & 31.16 & 6.40 & 5.0 & 1.48 & 1.69 \\
\hline E. nigrum & 9.76 & 9.02 & 30.68 & 28.18 & 4.38 & 4.15 & 1.26 & 1.06 \\
\hline E. albo marginatum & 11.16 & 10.37 & 36.73 & 34.29 & 6.19 & 4.93 & 1.70 & 1.12 \\
\hline E. tricolour & 9.35 & 8.04 & 31.55 & 30.59 & 4.04 & 3.55 & 1.42 & 0.99 \\
\hline LSD(P>0.05) & 1.13 & 1.10 & 3.01 & 2.83 & 1.16 & 0.70 & $\mathbf{0 . 3 3}$ & 0.35 \\
\hline \multicolumn{9}{|l|}{ cutting type } \\
\hline S. W & 11.46 & 9.77 & 35.09 & 30.83 & 5.30 & 4.40 & 1.35 & 1.24 \\
\hline S.HW & 9.48 & 9.18 & 32.23 & 31.32 & 5.31 & 4.78 & 1.50 & 1.33 \\
\hline HW & 9.45 & 8.84 & 33.64 & 31.02 & 5.14 & 4.04 & 1.55 & 1.08 \\
\hline $\operatorname{LSD}(P>0.05)$ & 0.98 & n.s. & 2.61 & n.s. & n.s. & 0.61 & n.s. & n.s. \\
\hline \multicolumn{9}{|l|}{ planting date } \\
\hline February & 10.87 & 10.46 & 39.82 & 34.84 & 7.39 & 6.0 & 1.72 & 1.43 \\
\hline May. & 9.40 & 8.07 & 27.49 & 27.27 & 3.11 & 2.82 & 1.21 & 1.01 \\
\hline LSD(P>0.05) & 0.80 & 0.78 & 2.13 & 2.0 & 0.82 & 0.50 & 0.24 & 0.25 \\
\hline
\end{tabular}

Table(6): Interaction effect between species, stem cutting type and planting date on root parameters per cutting.(Interaction between two factors).

\begin{tabular}{|c|c|c|c|c|c|c|c|c|}
\hline \multirow{3}{*}{ Treatments } & \multicolumn{8}{|c|}{ Root parameters } \\
\hline & \multicolumn{2}{|c|}{ Number of roots } & \multicolumn{2}{|c|}{$\begin{array}{l}\text { Length of } \\
\operatorname{roots}(\mathrm{cm})\end{array}$} & \multicolumn{2}{|c|}{$\begin{array}{l}\text { Fresh weight of } \\
\text { roots (gm) }\end{array}$} & \multicolumn{2}{|c|}{$\begin{array}{l}\text { Dry weight of } \\
\text { roots (gm) }\end{array}$} \\
\hline & $\begin{array}{l}\text { First } \\
\text { year }\end{array}$ & $\begin{array}{c}\text { Second } \\
\text { year }\end{array}$ & $\begin{array}{l}\text { First } \\
\text { year }\end{array}$ & $\begin{array}{c}\text { Second } \\
\text { year }\end{array}$ & $\begin{array}{l}\text { First } \\
\text { year }\end{array}$ & $\begin{array}{l}\text { Second } \\
\text { year }\end{array}$ & $\begin{array}{l}\text { First } \\
\text { year }\end{array}$ & $\begin{array}{c}\text { Second } \\
\text { year }\end{array}$ \\
\hline \multicolumn{9}{|l|}{ Species x Cutting type } \\
\hline E.reticulatum X S. W & 13.0 & 11.84 & 35.67 & 30.63 & 6.59 & $\mathbf{5 . 5 3}$ & 1.75 & 1.93 \\
\hline E. reticulatum X S.HW & 8.46 & 8.71 & 33.19 & 32.13 & 5.70 & 5.61 & 0.99 & 2.0 \\
\hline E. reticulatum $\mathbf{X} \mathbf{H W}$ & 9.33 & 8.33 & 38.10 & 30.72 & 6.90 & 3.85 & 1.70 & 1.15 \\
\hline E.nigrum X S. W & 10.62 & 9.25 & 32.73 & 27.02 & 6.35 & 4.13 & 1.49 & 0.97 \\
\hline E. nigrum X S.HW & $\mathbf{1 0 . 0 3}$ & 9.33 & 30.89 & 29.18 & 4.21 & 4.02 & 1.45 & 0.91 \\
\hline E. nigrum X HW & 8.63 & 8.50 & 28.43 & 28.34 & 2.59 & 4.30 & $\mathbf{0 . 8 5}$ & $\mathbf{1 . 3 0}$ \\
\hline E.albo marginatum X S. W & 11.88 & 9.95 & 37.06 & 34.43 & 4.92 & 4.20 & 1.29 & $\mathbf{0 . 8 2}$ \\
\hline E. albo marginatum X S.HW & 10.46 & 10.33 & 35.78 & 35.66 & 6.70 & 5.81 & 1.79 & 1.51 \\
\hline E. albo marginatum $\mathbf{X} \mathbf{H W}$ & 11.15 & 10.82 & 37.35 & 32.78 & 6.94 & 4.78 & 2.03 & 1.02 \\
\hline E.tricolour X S. W & $\mathbf{1 0 . 3 5}$ & 8.04 & 34.91 & 31.23 & 3.35 & 3.75 & 0.88 & $\mathbf{1 . 2 3}$ \\
\hline E. tricolour X S.HW & 8.99 & $\mathbf{8 . 3 8}$ & 29.06 & 28.32 & 4.64 & 3.69 & 1.76 & 0.89 \\
\hline E. tricolour $\mathbf{X} \mathbf{H W}$ & 8.71 & 7.70 & 30.69 & 32.22 & 4.12 & 3.23 & 1.63 & 0.86 \\
\hline $\operatorname{LSD}(\mathbf{P}>0.05)$ & 1.95 & 1.90 & 5.22 & 4.89 & 2.0 & 1.22 & $\mathbf{0 . 5 8}$ & 0.60 \\
\hline \multicolumn{9}{|l|}{ Species x Planting date } \\
\hline E. reticulatum $\mathbf{X}$ Feb. & 10.60 & 10.81 & 41.69 & 33.98 & 9.30 & 6.73 & 1.82 & 1.82 \\
\hline E. reticulatum X. May. & 9.93 & 8.44 & 29.62 & 28.34 & 3.49 & 3.27 & 1.13 & 1.56 \\
\hline E. nigrum $\mathbf{X}$ Feb. & 9.95 & 9.58 & 36.63 & 31.77 & 6.60 & 6.22 & 1.43 & 1.40 \\
\hline E. nigrum X May. & 9.57 & 8.48 & 24.73 & 24.59 & 2.17 & 2.08 & 1.09 & $\mathbf{0 . 7 3}$ \\
\hline E. albo marginatum X Feb. & 12.50 & 11.48 & 45.17 & 40.49 & 8.69 & 6.71 & $\mathbf{1 . 8 3}$ & 1.48 \\
\hline E. albo marginatum X May. & 9.83 & 9.25 & 28.28 & 28.09 & 3.68 & 3.14 & $\mathbf{1 . 5 8}$ & $\mathbf{0 . 7 5}$ \\
\hline E. tricolour X Feb. & 10.42 & 9.97 & 35.79 & 33.13 & 4.96 & 4.33 & 1.79 & 1.0 \\
\hline E. tricolour X May. & 8.28 & 6.11 & 27.32 & 28.05 & 3.12 & 2.78 & 1.05 & 0.99 \\
\hline $\mathrm{LSD}(\mathrm{P}>0.05)$ & 1.59 & 1.55 & 4.26 & 4.0 & 1.64 & 1.0 & 0.47 & 0.49 \\
\hline \multicolumn{9}{|l|}{ Cutting type $x$ Planting date } \\
\hline S. W X Feb. & 12.56 & 11.02 & 41.46 & 34.64 & 7.64 & 6.32 & 1.67 & 1.57 \\
\hline S. W X May. & 10.36 & 8.08 & 28.73 & 27.01 & 2.96 & 2.49 & $\mathbf{1 . 0 3}$ & 0.91 \\
\hline S.HW X Feb. & 10.24 & 10.76 & 37.89 & 36.05 & 7.12 & 6.25 & 1.57 & 1.50 \\
\hline S.HWX May. & 8.73 & 7.60 & 26.56 & 26.60 & 3.51 & 3.31 & 1.42 & 1.15 \\
\hline HW X Feb. & 9.79 & 9.59 & 40.12 & 33.83 & 7.40 & 5.42 & 1.91 & 1.21 \\
\hline HW X May. & 9.11 & 8.08 & 27.16 & 28.20 & 2.88 & 2.66 & 1.19 & 0.96 \\
\hline $\mathrm{LSD}(\mathrm{P}>0.05)$ & 1.38 & 1.34 & 3.69 & 3.46 & 1.42 & 0.86 & 0.41 & 0.43 \\
\hline
\end{tabular}


Table (7): Interaction effect between species, cutting type and planting date on root parameters per cutting.(Interaction between three factors together).

\begin{tabular}{|c|c|c|c|c|c|c|c|c|}
\hline \multirow{3}{*}{ Treatments } & \multicolumn{8}{|c|}{ Root parameters } \\
\hline & \multicolumn{2}{|c|}{ Number of roots } & \multicolumn{2}{|c|}{$\begin{array}{l}\text { Length } \\
\operatorname{roots}(\mathrm{cm})\end{array}$} & \multicolumn{2}{|c|}{$\begin{array}{l}\text { Fresh weight of } \\
\text { roots (gm) }\end{array}$} & \multicolumn{2}{|c|}{$\begin{array}{l}\text { Dry weight of } \\
\text { roots (gm) }\end{array}$} \\
\hline & $\begin{array}{l}\text { First } \\
\text { year }\end{array}$ & $\begin{array}{l}\text { Secon } \\
\text { d year }\end{array}$ & $\begin{array}{l}\text { First } \\
\text { year }\end{array}$ & $\begin{array}{l}\text { Second } \\
\text { year }\end{array}$ & $\begin{array}{l}\text { First } \\
\text { year }\end{array}$ & $\begin{array}{l}\text { Second } \\
\text { year }\end{array}$ & $\begin{array}{l}\text { First } \\
\text { year }\end{array}$ & $\begin{array}{l}\text { Second } \\
\text { year }\end{array}$ \\
\hline E. reticulatum X S. WX Feb. & 15.33 & 14.60 & 42.85 & 32.24 & 9.00 & 7.29 & 2.18 & 2.18 \\
\hline E. reticulatum X S. WX May. & 10.67 & 9.08 & 28.50 & 29.02 & 4.17 & 3.78 & 1.33 & 1.68 \\
\hline E. reticulatum X S.HWX Feb. & 8.0 & 9.33 & 37.42 & 37.18 & 7.92 & 7.93 & 0.97 & 2.32 \\
\hline E. reticulatum X S.HWX May. & 8.93 & 8.08 & 28.95 & 27.08 & 3.47 & 3.30 & 1.00 & 1.68 \\
\hline E. reticulatum X HW X Feb. & 8.48 & 8.50 & 44.80 & 32.52 & 10.98 & 4.98 & 2.32 & 0.97 \\
\hline E. reticulatum X HWX May. & 10.18 & 8.17 & 31.40 & 28.92 & 2.82 & 2.73 & 1.08 & 1.33 \\
\hline E. nigrum X S. WX Feb. & 9.93 & 8.50 & 39.90 & 32.04 & 10.88 & 6.82 & 2.03 & 1.39 \\
\hline E. nigrum X S. WX May. & 11.13 & $\mathbf{1 0 . 0}$ & 25.55 & 22.0 & 1.82 & 1.45 & 0.95 & 0.55 \\
\hline E. nigrum X S.HWX Feb. & 11.15 & 11.90 & 35.28 & 30.82 & 5.55 & 5.08 & 1.43 & 0.95 \\
\hline E. nigrum X S.HWX May. & 8.90 & 6.75 & 26.50 & 27.55 & 2.87 & 2.95 & 1.48 & 0.88 \\
\hline E. nigrum X HW X Feb. & 8.78 & 8.32 & 34.73 & 32.46 & 3.37 & 6.76 & 0.85 & 1.86 \\
\hline E. nigrum X HWX May. & 8.48 & 8.67 & 22.13 & 24.22 & 1.80 & 1.85 & 0.85 & 0.75 \\
\hline E. albo marginatum $\mathbf{X}$ S. WX Feb. & 12.75 & 11.15 & $\mathbf{4 4 . 2 3}$ & 40.73 & 7.15 & 6.32 & 1.45 & 1.07 \\
\hline E. albo marginatum X S. WX May. & 11.0 & 8.74 & 29.90 & 28.12 & 2.70 & 2.08 & 1.13 & 0.58 \\
\hline E. albo marginatum X S.HWX Feb. & 12.25 & 11.58 & 45.30 & 44.98 & 9.03 & 7.66 & 1.65 & 2.10 \\
\hline E.albo marginatum X S.HWX May. & 8.68 & 9.08 & 26.25 & 26.35 & 4.37 & 3.95 & 1.93 & 0.93 \\
\hline E. albo marginatum $\mathbf{X} \mathbf{H W} \mathbf{X}$ Feb. & 12.50 & 11.73 & 46.0 & 35.77 & 9.90 & 6.17 & 2.38 & 1.29 \\
\hline E. albo marginatum X HWX May. & 9.80 & 9.91 & 28.70 & 29.80 & 3.98 & 3.40 & 1.68 & 0.75 \\
\hline E. tricolour X S. WX Feb. & 12.25 & 9.83 & 38.85 & 33.58 & 3.55 & 4.84 & 1.03 & 1.64 \\
\hline E. tricolour X S. WX May. & 8.45 & 6.25 & 30.97 & 28.87 & 3.15 & 2.65 & 0.73 & 0.83 \\
\hline E. tricolour X S.HWX Feb. & 9.58 & 10.25 & 33.58 & 31.22 & 5.97 & 4.35 & 2.25 & 0.65 \\
\hline E. tricolour X S.HWX May. & 8.40 & 6.50 & 24.55 & 25.42 & 3.30 & 3.02 & 1.28 & 1.13 \\
\hline E. tricolour XHWX Feb. & 9.43 & 9.83 & 34.95 & 34.58 & 5.35 & 3.79 & 2.10 & 0.70 \\
\hline E. tricolour X HWX May. & 8.0 & 5.58 & 26.43 & 29.85 & 2.90 & 2.67 & 1.08 & $\mathbf{1 . 0 3}$ \\
\hline $\operatorname{LSD}(\mathbf{P}>0.05)$ & 2.76 & 2.68 & 7.38 & 6.92 & 2.83 & 1.72 & 0.82 & 0.85 \\
\hline
\end{tabular}

Wiese ( 2006). While, S.HW. cuttings planted in May had the lowest values ( 8.73 and 7.60 ) in the first and second years, respectively .

From Table (7) the interaction between species,cutting type and planting date significantly affected the number of roots . S.W. cuttings of E. reticulatum planted in February recorded the highest root numbers 15.33 and 14.60 in the first and second years, respectively. While , H.W. cuttings of E. tricolor planted in May recorded the lowest root numbers (8.0 and 5.58) in the first and second seasons, respectively .

\subsubsection{Length of roots per cutting $(\mathrm{cm})$}

Species showed significant variation in the length of roots in Table (5), the findings are in conformity with the work of Zalesny and Wiese (2006) ,the maximum length ( 36.73 and 34.29 $\mathrm{cm}$ ) were recorded in cuttings of E. albomarginatum in the first and second seasons, respectively .There were no significant differences in cutting type in the second year, However, no significant differences were observed between S.W. cuttings which recorded the maximum length $(35.09 \mathrm{~cm})$ and $H . W$. cutting in the first season $(33.64 \mathrm{~cm})$ Table (5), Whereas, Christopher et al.(2004) stated that cutting type had significant effect. The length of roots was significantly affected by planting date Table (5). These are in line with the results obtained by Yoo et al. (1996) who reported that planting date caused significant difference in root length, the greater root lengths ( 39.82 and $34.84 \mathrm{~cm}$ ) were noticed in February.The interaction of species and cutting type was found to be significant Table (6). The length of roots was maximum in H.W. cuttings of $E$. reticulatum in the first year and with S.H.W. cutting of E.albo-marginatum in the second year which produced $(38.10$ and $35.66 \mathrm{~cm})$ in the first and second years, respectively. Table (6) indicated that the interaction between species and planting date significantly affected the root length. The longest root lengths (45.17 and $40.49 \mathrm{~cm}$ ) were recorded in cuttings of E. albomarginatum planted in February, while ,the least values $(24.73$ and $24.59 \mathrm{~cm})$ were recorded in cuttings of E. nigrum planted in May in the first and second years respectively. The interaction between cutting type and planting 
date had significant effect on the length of roots. Table (6) .The data showed that S.W. and S.HW. cuttings in February plantation produced the longest root lengths (41.46 and $36.05 \mathrm{~cm}$ ) in the first and second years, respectively .

The interaction between species, cutting type and planting time significantly affected the length of the roots Table (7) , longest roots ( 46.0 and $44.98 \mathrm{~cm}$ ) were produced with H.W. and S.HW. cuttings of E. albo-marginatum planted in February in the first and second years, respectively .

\subsubsection{Fresh and dry weight of roots ( $\mathrm{gm}$ )}

It was revealed from Table ( 5 ) that fresh and dry weight of roots were significantly affected by species. Zalesny and Wiese ( 2006) also made similar observation, E. reticulatum and E.albo-marginatum achieved the highest root fresh weights ( 6.40 and $6.19 \mathrm{gm}$ ) and the highest dry weight (1.48 and $1.70 \mathrm{gm})$ in the first year ,while the higthest fresh weight of roots in the second year ( 5.0 and $4.93 \mathrm{gm}$ ) and the highest dry weight of roots in the second year were 1.69 and $1.12 \mathrm{gm}$, respectively. Table ( 5 ) showed that cutting type did not have any significant effect on fresh and dry weight of roots in the first year. However, significant effect on fresh weight of roots was noticed in the second year which is in close conformity to the finding of Laura et al. (1994). Table (5) revealed that planting date had significant effect, the highest fresh and dry weights (7.39 and $1.72 \mathrm{gm})$ were obtained in the first year and 6.0 and $1.43 \mathrm{gm}$ in the second one in February plantation .The differences in the weight of roots might be due to the fact that as the cuttings planted in February got favorable climatic condition hence, increased the number of roots and root length were recorded which resulted in heavier root weight . Table (6) showed that there was significant interaction of species and cutting type. More fresh and dry weight were achieved in H.W. and S.HW. cuttings of E. albomarginatum and E. reticulatum in the first and second years, respectively. The interaction between species and planting date was significant. Table (6) indicated that cuttings of $E$. reticulatum and E.albo-marginatum planted in February achieved the highest fresh and dry weight of roots in the first season, while the least value of fresh and dry weight was noticed in cuttings of E. tricolor and E. nigrum planted in May in both years. The interaction between type of cutting and planting date was also found to be significant, similar to the finding of Kraiem et al.(2010) . Table (6) indicated that S.W. cuttings in February plantation recorded the highest fresh weight of roots while the highest dry weight of roots was obtained with H.W. cutting planted in Feb. in the first season followed by S.W. cutting planted in Feb. in the second year.

Table (7) showed that the three factors interaction between species, cutting type and planting date had significant effect, (Zalesny and Wiese, 2006). They also obtained similar results. H.W. and S.HW. cuttings of E. reticulatum in February plantation recorded the highest fresh weight ( 10.98 and $7.93 \mathrm{gm})$ in, the first and second years, respectively, while the highest dry weight ( 2.38 and $2.32 \mathrm{gm}$ ) recorded in H.W. and S.HW. cuttings of E. albo-marginatum and E. reticulatum planted in February in the first and second years, respectively .

\subsection{Vegetative growth}

\subsubsection{Number of shoots per cutting}

The results in Table (8) indicated that species had significant effect on the number of shoot, cuttings of E.albo-marginatum produced the highest number of shoots (4.20 and 3.32/ cutting) while,cuttings of $E$. reticulatum produced the lowest number of shoots ( 2.87 , 2.33 ) in both seasons, respectively. There were significant differences in cutting type on the average number of shoots produced, the number of shoots produced from H.W. and S.H.W. were not significantly different from each other but was higher than the number obtained from S.W cuttings Table (8) .These are in the line of the results obtained by Agbo and Obi (2007) on Gongronema latifolia. This implies that the cutting from basal part develops more shoots probably because of its higher carbohydrate reserve .The planting date also had significant effect , May plantation produced the highest number of shoots( 3.64 and 3.52/ cutting) in the first and second seasons, respectively Table (8) .

The interaction between species and cutting type had significant effect, E. albo- marginatum with H.W and S.HW produced the highest number of shoots ( 4.91 and 4.75 ) in the first season and ( 4.20 and 4.17 ) in the second one, respectively Table (9). Significant effect between species and planting date was also observed , E.albo-marginatum and E. tricolor planted in May produced the highest number of shoots ( 4.62 and 4.20) and (3.89 and 3.97) in the first and second seasons, respectively Table (9).

The interaction between cutting type and planting time (Table 9) showed that H.W. 
Table (8): Single effect of species, stem cutting type and planting date on the vegetative parameters per cutting.

\begin{tabular}{|c|c|c|c|c|c|c|}
\hline \multirow{3}{*}{ Treatments } & \multicolumn{6}{|c|}{ vegetative parameters } \\
\hline & \multicolumn{2}{|c|}{ Number of shoots } & \multicolumn{2}{|c|}{$\begin{array}{l}\text { Length of longest shoot } \\
(\mathrm{cm})\end{array}$} & \multicolumn{2}{|c|}{ Number of leaves } \\
\hline & $\begin{array}{l}\text { First } \\
\text { year }\end{array}$ & $\begin{array}{c}\text { Second } \\
\text { year }\end{array}$ & $\begin{array}{l}\text { First } \\
\text { year }\end{array}$ & $\begin{array}{c}\text { Second } \\
\text { year }\end{array}$ & First year & $\begin{array}{c}\text { Second } \\
\text { year }\end{array}$ \\
\hline \multicolumn{7}{|l|}{ Species } \\
\hline E. reticulatum & 2.87 & 2.33 & 16.34 & 14.60 & 22.08 & 17.50 \\
\hline E. nigrum & 2.95 & 2.36 & 17.73 & 17.81 & 23.19 & 18.38 \\
\hline E. albo marginatum & 4.20 & 3.32 & 14.30 & 13.22 & 28.86 & 25.05 \\
\hline E. tricolour & 3.44 & 3.04 & 20.38 & 14.89 & 32.16 & 25.90 \\
\hline $\operatorname{LSD}(\mathbf{P}>0.05)$ & 0.63 & 0.56 & 2.22 & 1.75 & 3.40 & 2.59 \\
\hline \multicolumn{7}{|l|}{ cutting type } \\
\hline S. W & 2.41 & 1.60 & 16.61 & 15.15 & 20.74 & 17.0 \\
\hline S.HW & 3.75 & 3.23 & 17.65 & 16.16 & 28.15 & 22.92 \\
\hline HW & 3.93 & 3.46 & $\mathbf{1 7 . 3 1}$ & 14.08 & 30.83 & 25.19 \\
\hline LSD $(\mathbf{P}>0.05)$ & 0.54 & 0.40 & n.s. & 1.51 & 2.94 & 2.24 \\
\hline \multicolumn{7}{|l|}{ planting date } \\
\hline February & 3.09 & 2.01 & 18.22 & 14.05 & 26.51 & 17.54 \\
\hline May. & 3.64 & 3.52 & 16.16 & 16.20 & 26.64 & 25.88 \\
\hline LSD $(P>0.05)$ & 0.44 & 0.40 & 1.57 & 1.24 & n.s. & 1.83 \\
\hline
\end{tabular}

Table (9): Interaction effect between species ,stem cutting type and planting date on the vegetative parameters per cutting (Interaction between two factors).

\begin{tabular}{|c|c|c|c|c|c|c|}
\hline \multirow{3}{*}{ Treatments } & \multicolumn{6}{|c|}{ vegetative parameters } \\
\hline & \multicolumn{2}{|c|}{ Number of shoots } & \multicolumn{2}{|c|}{$\begin{array}{c}\text { Length of longest } \\
\text { shoot }(\mathrm{cm})\end{array}$} & \multicolumn{2}{|c|}{ Number of leaves } \\
\hline & $\begin{array}{l}\text { First } \\
\text { year }\end{array}$ & $\begin{array}{c}\text { Second } \\
\text { year }\end{array}$ & $\begin{array}{l}\text { First } \\
\text { year }\end{array}$ & $\begin{array}{c}\text { Second } \\
\text { year }\end{array}$ & $\begin{array}{l}\text { First } \\
\text { year }\end{array}$ & $\begin{array}{c}\text { Second } \\
\text { year }\end{array}$ \\
\hline \multicolumn{7}{|l|}{ Species x Cutting type } \\
\hline E.reticulatum X S. W & 2.09 & 1.34 & 16.05 & 16.16 & 20.04 & 16.41 \\
\hline E. reticulatum X S.HW & 3.39 & 2.76 & 15.44 & 14.68 & 23.54 & 17.0 \\
\hline E. reticulatum $\mathbf{X} \mathbf{H W}$ & 3.14 & 2.90 & $\mathbf{1 7 . 5 4}$ & 12.95 & 22.66 & 19.08 \\
\hline E.nigrum X S. W & 1.86 & 1.39 & 15.70 & 16.08 & $\mathbf{1 7 . 5 0}$ & 22.37 \\
\hline E. nigrum X S.HW & 3.12 & 2.62 & 21.23 & 20.29 & 26.53 & 19.45 \\
\hline E. nigrum $\mathbf{X} \mathbf{H W}$ & 3.85 & 3.09 & 16.28 & 17.06 & 25.55 & 22.37 \\
\hline E.albo marginatum $\mathbf{X} \mathbf{S} . \mathbf{W}$ & 2.95 & 1.60 & 13.37 & 14.01 & 19.34 & $\mathbf{1 7 . 9 5}$ \\
\hline E. albo marginatum X S.HW & 4.75 & 4.17 & 14.70 & 13.35 & 30.11 & 27.07 \\
\hline E. albo marginatum $\mathbf{X} \mathbf{H W}$ & 4.91 & 4.20 & 14.84 & 12.30 & 37.13 & 30.12 \\
\hline E.tricolour X S. W & 2.75 & 2.07 & 21.32 & 14.33 & 26.09 & 20.33 \\
\hline E. tricolour X S.HW & 3.74 & 3.38 & 19.24 & 16.33 & 32.41 & 28.16 \\
\hline E. tricolour X HW & 3.82 & 3.68 & 20.57 & 14.01 & 37.98 & 29.20 \\
\hline $\operatorname{LSD}(\mathbf{P}>0.05)$ & 1.09 & 0.98 & 3.84 & 3.03 & 5.88 & 4.49 \\
\hline \multicolumn{7}{|l|}{ Species x Planting date } \\
\hline E. reticulatum $\mathbf{X}$ Feb. & 2.47 & 1.64 & 18.58 & 12.99 & 23.49 & 13.83 \\
\hline E. reticulatum X. May. & 3.27 & 3.02 & 14.10 & 16.20 & 20.67 & 21.17 \\
\hline E. nigrum X Feb. & 3.11 & 1.86 & 18.94 & 19.69 & 26.14 & 16.57 \\
\hline E. nigrum X May. & 2.78 & 2.87 & 16.53 & 15.93 & 20.24 & 20.19 \\
\hline E. albo marginatum $\mathbf{X}$ Feb. & 3.78 & 2.44 & 13.68 & 10.24 & 25.13 & 21.0 \\
\hline E. albo marginatum $\mathbf{X}$ May. & 4.62 & 4.20 & 14.93 & 16.20 & 32.58 & 29.10 \\
\hline E. tricolour X Feb. & 2.98 & 2.11 & 21.68 & 13.30 & 31.27 & 18.75 \\
\hline E. tricolour X May. & 3.89 & 3.97 & 19.07 & 16.48 & 33.05 & 33.05 \\
\hline LSD $(P>0.05)$ & $\mathbf{0 . 8 9}$ & 0.80 & 3.14 & 2.47 & 4.80 & 3.66 \\
\hline \multicolumn{7}{|l|}{ Cutting type $x$ Planting date } \\
\hline S. W X Feb. & 1.76 & 0.21 & 16.26 & 13.13 & 19.06 & 12.68 \\
\hline S. W X May. & 3.06 & 2.99 & 16.97 & 17.16 & 22.42 & 21.33 \\
\hline S.HW X Feb. & 3.76 & 2.84 & 18.19 & 15.27 & 27.85 & 18.98 \\
\hline S.HWX May. & 3.74 & 3.63 & 17.11 & 17.06 & 28.44 & 26.87 \\
\hline HW X Feb. & 3.74 & 3.0 & 20.21 & $\mathbf{1 3 . 7 6}$ & 32.61 & 20.96 \\
\hline HW X May. & 4.13 & 3.93 & 14.40 & 14.39 & 29.04 & 29.43 \\
\hline LSD(P>0.05) & 0.77 & 0.69 & 2.72 & 2.14 & 4.16 & 3.17 \\
\hline
\end{tabular}


Table (10): Interaction effect between species ,stem cutting type and planting date on vegetative parameters per cutting (Interaction between three factors together).

\begin{tabular}{|c|c|c|c|c|c|c|}
\hline \multirow{3}{*}{ Treatments } & \multicolumn{6}{|c|}{ Vegetative parameters } \\
\hline & \multicolumn{2}{|c|}{$\begin{array}{l}\text { Number of } \\
\text { shoots }\end{array}$} & \multicolumn{2}{|c|}{$\begin{array}{c}\text { Length of } \\
\text { longest shoot } \\
(\mathrm{cm})\end{array}$} & \multicolumn{2}{|c|}{ Number of leaves } \\
\hline & $\begin{array}{l}\text { First } \\
\text { year }\end{array}$ & $\begin{array}{c}\text { Second } \\
\text { year }\end{array}$ & $\begin{array}{l}\text { First } \\
\text { year }\end{array}$ & $\begin{array}{c}\text { Second } \\
\text { year }\end{array}$ & $\begin{array}{l}\text { First } \\
\text { year }\end{array}$ & $\begin{array}{c}\text { Second } \\
\text { year }\end{array}$ \\
\hline E. reticulatum X S. WX Feb. & 1.25 & 0.00 & 16.63 & 13.43 & 20.57 & 11.50 \\
\hline E. reticulatum X S. WX May. & 2.92 & 2.67 & 15.48 & 18.90 & $\mathbf{1 9 . 5 0}$ & 21.32 \\
\hline E. reticulatum X S.HWX Feb. & 3.57 & 2.35 & $\mathbf{1 7 . 1 8}$ & 14.09 & 25.75 & 14.33 \\
\hline E. reticulatum X S.HWX May. & 3.20 & 3.17 & 13.70 & 15.28 & 21.32 & 19.67 \\
\hline E. reticulatum X HW X Feb. & 2.60 & 2.57 & 21.95 & 11.47 & 24.15 & 15.66 \\
\hline E. reticulatum X HWX May. & 3.67 & 3.22 & 13.13 & 14.43 & 21.17 & 22.50 \\
\hline E. nigrum X S. WX Feb. & 1.72 & 0.25 & 15.52 & $\mathbf{1 7 . 1 0}$ & 18.92 & 11.46 \\
\hline E. nigrum X S.FWX May. & 2.0 & 2.52 & 15.88 & 15.08 & 16.07 & 15.17 \\
\hline E. nigrum X S.HWX Feb. & 3.75 & 2.83 & 22.30 & 20.48 & 29.58 & $\mathbf{1 7 . 0 8}$ \\
\hline E. nigrum X S.HWX May. & 2.50 & 2.40 & 20.15 & 20.10 & 23.48 & 21.82 \\
\hline E. nigrum X HW X Feb. & 3.85 & 2.50 & 19.0 & 21.49 & 29.92 & 21.17 \\
\hline E. nigrum X HWX May & 3.85 & 3.67 & 13.55 & 12.63 & 21.17 & 23.57 \\
\hline E. albo marginatum X S. WX Feb. & 2.08 & $\mathbf{0 . 1 7}$ & 12.70 & 9.13 & 13.25 & 14.84 \\
\hline E. albo marginatum X S. WX May. & 3.82 & 3.03 & 14.05 & 18.90 & 25.42 & 21.07 \\
\hline E. albo marginatum X S.HWX Feb. & 4.18 & 3.75 & 13.80 & 11.42 & 24.98 & 24.75 \\
\hline E.albo marginatum X S.HWX May. & 5.32 & 4.60 & 15.60 & 15.28 & 35.25 & 29.40 \\
\hline E. albo marginatum X HW X Feb. & 5.10 & 3.42 & 14.53 & $\mathbf{1 0 . 1 7}$ & 37.18 & 23.42 \\
\hline E. albo marginatum X HWX May. & 4.72 & 4.97 & 15.15 & 14.42 & 37.07 & 36.83 \\
\hline E. tricolour X S. WX Feb. & 2.0 & 0.42 & 20.17 & 12.89 & 23.50 & 12.92 \\
\hline E. tricolour X S. WX May. & 3.50 & 3.73 & 22.47 & 15.78 & 28.67 & 27.75 \\
\hline E. tricolour X S.HWX Feb. & 3.55 & 2.42 & $\mathbf{1 9 . 5 0}$ & 15.08 & 31.10 & $\mathbf{1 9 . 7 5}$ \\
\hline E. tricolour X S.HWX May. & 3.92 & 4.35 & 18.98 & $\mathbf{1 7 . 5 8}$ & 33.73 & 36.57 \\
\hline E. tricolour XHWX Feb. & 3.40 & 3.50 & 25.37 & 11.92 & 39.20 & 23.58 \\
\hline E. tricolour X HWX May. & 4.25 & 3.85 & 15.77 & 16.10 & 36.75 & 34.82 \\
\hline LSD $(P>0.05)$ & $\mathbf{1 . 5 3}$ & 1.39 & 5.43 & 4.28 & 8.32 & 6.35 \\
\hline
\end{tabular}

cuttings planted in May had the highest number of shoots ( 4.13 and 3.93 ) in the first and second seasons, respectively, while, S.W. cuttings planted in February produced the least number of shoots ( 1.76 and 0.21$)$ in both years, respectively. Table (10) indicated that the three factors interaction significantly affected the number of shoots, the highest number ( 5.32 and 4.97) were produced with S.HW and H.W cuttings of E.albo-marginatum planted in May in the first and second seasons, respectively.

\subsubsection{Length of the longest shoot per cutting $(\mathbf{c m})$}

Table (8) showed that species were significantly different from each other in both seasons, it is noticed that it was the longest $(20.38 \mathrm{~cm})$ in E. tricolor in the first year and $(17.81 \mathrm{~cm})$ in E.nigrum in the second season. With regard to the type of cutting, significant differences were recorded S.HW. produced the longest shoot ( 17.65 and $16.16 \mathrm{~cm}$ ) in both seasons, respectively (Table 8). The present result differs from the finding of Agbo and Obi
(2007) on Gongronema latifolia who observed that H.W. cuttings had the longest shoot length The significant effect of planting date was observed, which is in close conformity to the finding of Bannister and Watt (1995) on Crataegus monogyna. It was revealed from Table (8) that the greatest length (18.22 and $16.20 \mathrm{~cm}$ ) were achieved when cuttings were planted in February in the first year and in May plantation in the second,respectively. The obtained data revealed that the responses to the interaction between species and cutting type was significant Table (9) E. tricolor with S.W. cuttings gave the longest shoot length $(21.32 \mathrm{~cm})$ in the first year, however, E. nigrum with S.HW. cuttings gave the longest shoot length $(20.29 \mathrm{~cm})$ in the second season. Interaction between species and planting date had significant effect Table (9). E. tricolor and E. nigrum cuttings planted in February recorded the longest shoot length $(21.68$ and $19.69 \mathrm{~cm})$ in the first and the second seasons, respectively, while the lowest length of shoots (13.68 and 10.24) in E.albo- 
marginatum were noticed in Feb. plantation. This might be due to that some species have different shoot length at different planting dates . Table (9) shows the interaction between cutting type and planting time significantly affected the longest shoot length. February plantation with H.W cuttings produced the longest shoot $(20.21 \mathrm{~cm})$ in the first season, followed by May plantation with S.W. and S.HW. cuttings which produced the shoot length( 17.16 and $17.06 \mathrm{~cm}$ ), in the second year, respectively.

Data in Table (10) revealed that the three factors interaction was significantly different among the treatments, the longest shoot length ( 25.37 and $21.49 \mathrm{~cm}$ ) were produced with H.W. cuttings of E. tricolor and E. nigrum planted in February, in the first and second seasons, respectively .

\subsubsection{Number of leaves per cutting}

Table (8) showed that the number of leaves was observed to be affected significantly by species. This result does not agree with the finding of Aminul et al.( 2010 ), it was the highest ( 32.16 and 25.90 ) for E. tricolor in both years respectively. Significant effect of cutting type was noticed, H.W. cuttings gave the highest number of leaves ( 30.83 and 25.19 ) in both seasons respectively Table (8). Similar results were obtained by Agbo and Obi ( 2007 ) . The highest number of leaves may be due to increased shoot development coupled with higher food reserve in hard wood cutting which resulted in significant higher number of leaves . Significant effect of planting date was observed in the the second year, it was the highest ( 25.88 ) in May plantation (Table 8). The data in Table (9) indicated that the interaction effect between species and type of cutting significantly effected the number of leaves. H.W. cuttings of $E$. tricolor and E.albo-marginatum produced the highest number of leaves ( 37.98 and 30.12) in the first and second years ,respectively. While, E. nigrum and E.recticulatum with S.W cuttings produced a minimum number of leaves ( 17.50 and 16.41) in the first and second seasons, respectively. The interaction effect between species and planting time (Table 9 ) was also found to be significant. E. tricolor cuttings planted in May resulted in more leaves ( 33.05 , 33.05 ) in both years, respectively. Perusal of Table (9) revealed that interaction effect between cutting type and planting date on the number of leaves concerned H.W. cuttings planted in February and May. produced the highest number of leaves ( 32.61 and 29.43 ) in the first and second years, respectively .

As far as the interaction between species, type of cutting and planting time were significantly effected Table (10), H.W. cuttings of E. tricolor in February and E.albomarginatum planted in May produced the highest number of leaves (39.20 and 36.83) in the first and second years, respectively.

Conclusion and Recommendation: It can be concluded that various species propagated through different types of stem cutting in different planting dates exhibited variability in rooting percentage and developed cuttings and can be important to multiply Eranthemum plant . The study suggests that the vegetative propagation of Eranthemum species of E. albomarginatum and E. nigrum could be achieved by semi- hard wood cuttings, while E. nigrum by hard wood and semi- hard wood cuttings , However, vegetative propagation of $E$. reticulatum could be achieved by any type of cuttings particularly when cuttings of all species are planted in February.

\section{REFERENCES}

Agbo C.U. and Obi I.U. (2007). Variability in propagation potentials of stem cuttings of different physiological ages of Gongronema latifolia , Benth. World Journal of Agricultural Sciences , 3 (5) : 576-581.

Aini Nor A.S., Guanih V.S. and Isnail N.A. (2010) . Effect of cutting positions and growth regulators on rooting ability of Gonystylus bancanus . African Journal of Plant Science , 4 (8) : 290-295.

Aminul Islam, A.K.M. Zahira Yaakob , Nurina Amar and Mohamed Osman. (2010). Propagation potentials of gynotypes and different physiological ages of stem cuttings in Jatropha curcas L. Journal of Agricultural Science, 2 (4) : 75-82.

Araya H.T. , Soundy P., OU. Toit E.S. and Mudau F.N. (2007) . Influence of cutting position, medium, hormone and season on rooting of bush tea ( Athrixia phylicoides DC. ) stem cuttings . Medicinal and Aromatic Plants Science and Biotechnology , 1 (2): 243-252.

Bannister N.R. and Watt T.A. (1995). Effect of cutting on the growth of Crataegus monogyna ( Hawthorn ) in hedges . Journal of Environmental Management, 45 (4) : 395410. 
Bhardwaj D. and Mishra V. ( 2005 ). Vegetative propagation of Ulmus villosa : effect of plant growth regulators, collection time , type of donor and position of shoot on adventitious root formation in stem cuttings . New Foreste , 29 ( 2 ) : 105-116.

Christopher B. Cerveny, Gibson L. , James and Barrett E. (2006). Influence of stem cutting location on propagation of Murraya paniculata and Tecoma stans. Hortscience, $41: 861-889$.

Francois Mankessi Abin, Saya R., Mehnie Toto and Olivier Monteuuis . (2010). Propagation of Eucalyptus urophylla $\mathrm{x}$ Eucalyptus grandis clones by rooted cuttings : Influence of genotype and cutting type on rooting ability . Propagation of Ornamental Plants , 10 ( 1 ) : 42-49.

Kamal F. Elkhalifa and Hamad, Al-Mufarrij (2006) . Propagation of Cordia mixa L. by stem cuttings . Pakistan Journal of Biological Sciences 9( 1 ) : 176-178.

Kibblen H.M.E. Johnston and Williams R. R. (2004) . Adventitious root formation in cuttings of Backhousia cibriodora F. Muell : 1-plant genotype, juvenility and characteristics of cuttings. Scientia Horticulture , 102 (1) : 133-143.

Koyuncu Fatma and Senel Eylem (2003). Rooting of black mulberry (Morus nigra L.) hard wood cuttings . Journal of Fruit and Ornamental Plant Research , 11: 53-57.

Kraiem W.Z. Aidi Wannes, Zairi A. and Ezzili B. (2010) . Effect of cutting date and position on rooting ability and fatty acid composition of carignan ( Vitis vinifera L. ) shoot. Scientia Horticulturae , 125 : 146-150.

Laura G. Jull, Stuart, Werren L., and Frank A. Blazich (1994). Rooting Yoshino cryptomeria stem cuttings as influenced by growth stage , branch order and IBA treatment . Hortscience , 29 : 1498-1538.

Palanisany K. Pramod Kumar (1997). Effect of position,size of cuttings and environmental factors on adventitious rooting in neem (Azadirachta indica A. Juss) . Forest Ecology and Management , 98 (3) : 277-280.

Paul H. Henry, Frank, Blazich A.and Eric Hinesley L. (1992) . Vegetative propagation of Eastern red cedar by stem cuttings . Hort. science, $27: 1250-1345$.

Paula M. Pijut, Melanie M.S. and Moore J. (2002) . Early season soft wood cuttings effective for vegetative propagation of Juglans cinerea . Hortscience , 37: 623-717.

Stankova T. and Panetosos K. (1997). Vegetative propagation of Cupressus sempervirens L. of cretan origin by soft wood stem cuttings. Silvae Genetica , 46(2-3) : 137-144.

Tetsumura Takaya , Ryutaro , Tao and Akira sugiura . (2001). Some factors affecting the rooting of softwood cuttings of Japanese persimmon J. Japan. Soc. Hort. Sci., 70(3) : 275- 280

Urszula Nawrocka ,Grzekowiak and Wojciech Grze Kowiak ( 2003 ) .Rooting of Azalea shoot cuttings depending on the degree of lignification . Dendro Biology, 49 : 53-56.

Yeboah J. S.T. Lowor and Amoah F.M.(2009) . The rooting performance of Shea(Vitellaria paradoxa gaertn ) stem cuttings as influenced by wood type, sucrose and rooting hormone . Scientific Research and Essay , 4 ( 5 ) : 521525.

Yoo Yong Kweon, Kim and Ki Sun . (1996) . Seasonal variation in rooting ability, plant hormones , carbohydrate, nitrogen , starch and soluble sugar contents in cuttings of white Forsythia ( Abliopyllum distichum Nakai ).J. Kor.Soc.Hort.Sci.,37 (4) : 554-560.

Zalesny R.S. and Wiese A.H. (2006) . Data of shoot collection, genotype and original shoot position affect early rooting of dormant hard wood cuttings of Populus. Silva Genetica, 55 (4-5 ) : 169-182. 


\title{
تأثير النوع النباتى ، نوع العقلة الساقية وموعد الزراعة على التكاثر الخضري

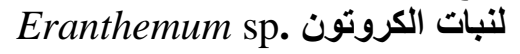

\author{
شميم مصطقى محمود \\ قسم البساتين ـ كلية ناصر للعلوم الزر اعية - جامعة عدن - اليمن
}

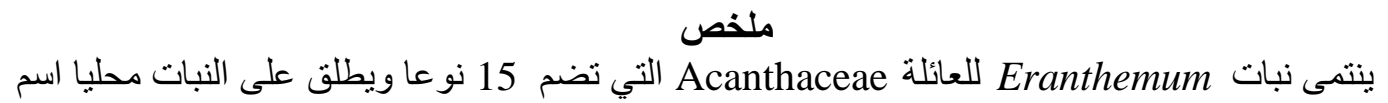

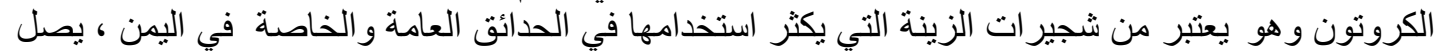

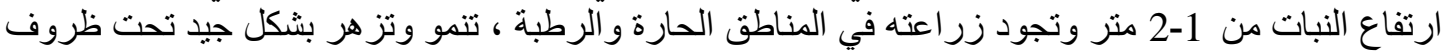

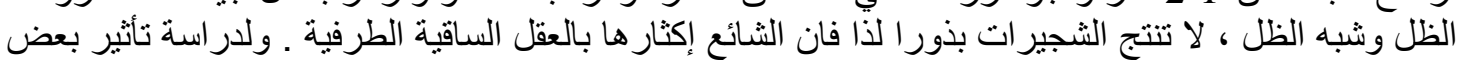

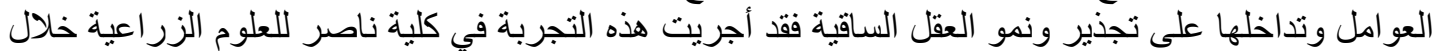

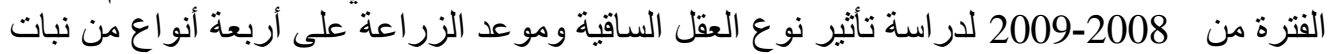

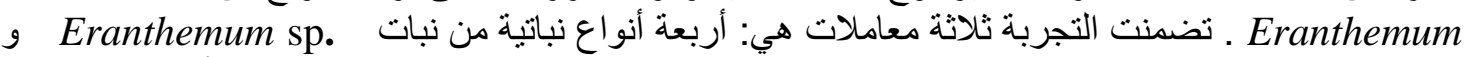

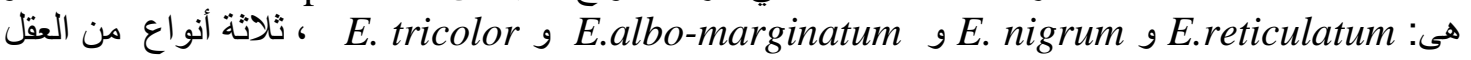

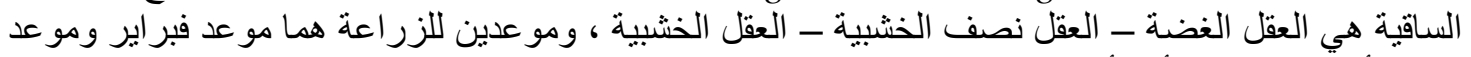

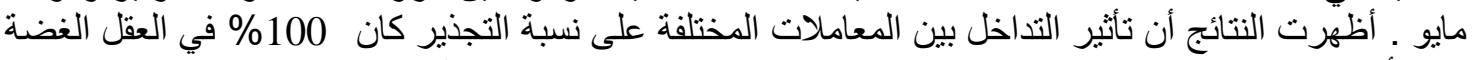

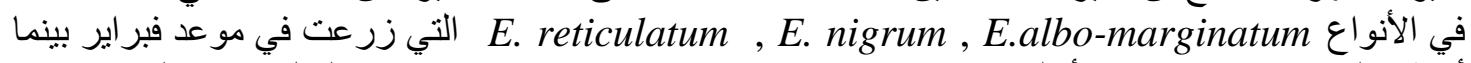
أعطى النوع E. tricolor أعلى نسبة تجذير (

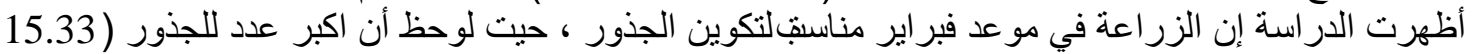

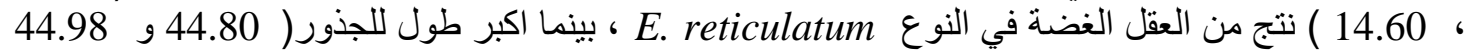

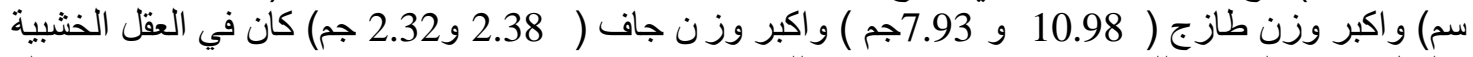

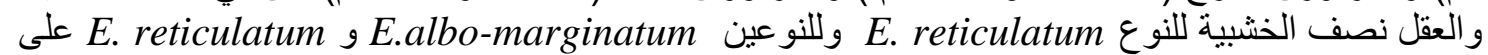

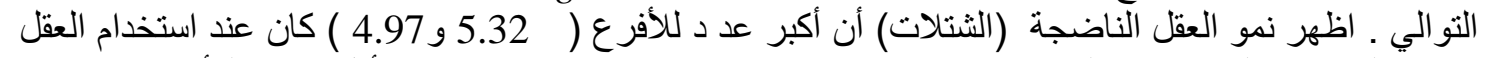

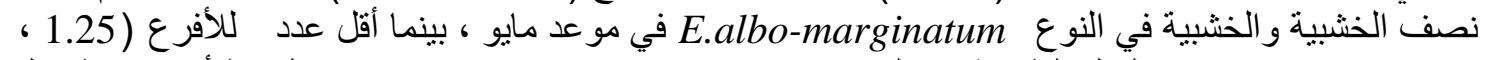

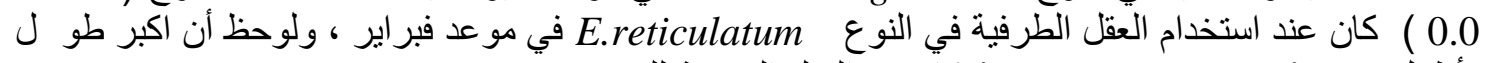

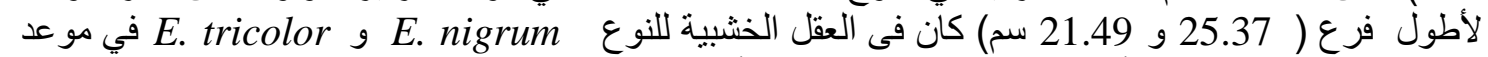

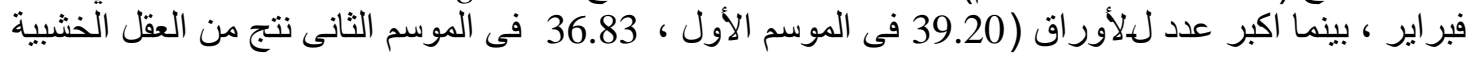

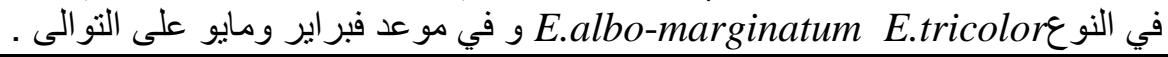

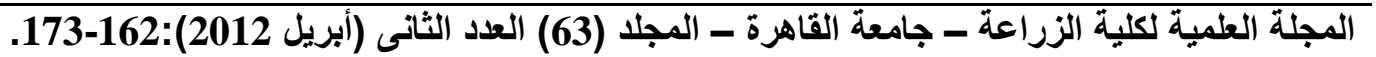

